\title{
LEARNING MOTIVATIONS, STYLES AND EXPECTATIONS OF STUDENTS - A SURVEY AT THE UNIVERSITY OF DEBRECEN
}

\author{
Tímea Gál ${ }^{1}$, Peter Popovics² ${ }^{2}$ Georgina Árváné Ványi ${ }^{3}$
}

\begin{abstract}
${ }^{1,2,3}$ University of Debrecen, Faculty of Economics and Business, Institute of Applied Economics Sciences, Department of Enterprise Development, 138 Böszörményi Str., Debrecen, Hungary 4032

19gal.timea@econ.unideb.hu, ${ }^{2}$ popovics.peter@econ.unideb.hu, ${ }^{3}$ arvane.vanyi.georgina@econ.unideb.hu
\end{abstract}

\begin{abstract}
Based on the experience of the authors, today's university students have different learning habits, expectations of learning and knowledge compared to previous generations. This raises the question of how traditional teaching, teaching methods effectively suited to their development. In this study, the authors examined with quantitative method the expectations of bachelor and master students concerning the business education at university. The survey was conducted among university students assessing whether students with different BSc/BA or MSc/MA majors show the willingness to continue their studies, and the authors were interested in their expectations concerning the business higher education. The authors also tried to find answers in the survey how well-prepared the students feel for the offered opportunities by today's market environment, or may prefer proceeding with their studies. Among the issues authors searched what are the most effective ways of learning for them, based on learning style, what motivates them to continue learning. What kind of education form is preferred by them to continue studying? They also respond the need of having theoretical and practical knowledge and the importance of developing practical life skills. In addition, it has also been surveyed what other expectations the students have in continuing their studies with regard to the institutions. The authors of this paper are working as team coaches at the Team Academy Debrecen. In the last six years, they worked with numerous teams and have experiences in developing students' skills in teams.
\end{abstract}

Keywords: Higher Education, Motivation, Expectation, Learning Styles.

(JEL Classification: A22)

\section{Introduction}

\section{Expectations towards higher education}

Recently the higher education has been criticized a lot because of its obsolete structure, and that it prepares the students to get their diploma instead of the expectations of the labour market. The research on expectations to higher education is of high interest among the researchers and the educators. It is important to get to know the expectations since the training programmes could be more tailored and have a higher satisfaction on both sides of the service providers and the 'customers' (i.e. students). Expectations on higher education are generally connected with the world of labour and the required competences. According to BODA and STOCKER (2012), talented students realize themselves (or their family teach it for them) that their expectations must be determined in connection with their employability. Unfortunately, in Hungary filling the timespan of being a university student to the maximum has become a trend phenomenon which aim is not to increase the relevant knowledge but to maintain a distance from the labour market. Another trend is getting the paper (degree) instead of acquiring the knowledge with the lowest effort (Boda And Stocker 2012).
According to Farrington (2002) the following factors can be realistically expected from the higher education institutions (HEIs) by the students:

- flexible, short courses at a convenient time and place for the students,

- competent educators who are able to communicate the complex theories in a clear and understandable way,

- recognition of the previous knowledge by the educators and the degree program,

- honesty concerning the labour market relevance of the program,

- and the HEI knows and understands the students' motivations.

Concerning the Hungarian research fields, the doctoral dissertation of Mihály (2008) is worth highlighting as she analysed the criteria of student satisfaction in the mass education. She also determined the other influencing factors of the satisfaction, e.g. the time factor, the role of sociodemographic factors, the influence of cognitive dissonance and contrast effect, and the issue of identity, which are all biasing elements for the customers' thinking of quality.

Horváth (2014) formed clusters based on the student expectations and perception. In forming the clusters the 
following expectations were significant in different orders of the clusters:

- convenience,

- flexibility,

- labour market relevance,

- support system,

- qualifying the learning-teaching,

- partnership.

\section{Learning motivation}

More and more research deal with the learning motivation of the students, since without motivation the education and thus the learning cannot be effective for sure. It is proven that the learning motivation is influenced by the organizational process of the education-teaching-learning (Báthory, 1992).

Motivation is an internal mind-set which inclines the people to behave in a way or make actions (Roóz and Heidrich 2013).

HOULE (1961) defined 3 main motivators in his research which inclines them to continue their studies in the higher education: learning motivation, goal orientation and action orientation. Goal-oriented students chose the university, because they see the tool in the higher education to build a career by getting a special qualification. Concerning the action-oriented students, he found that they were motivated by the fact that they could meet new people, build new contacts, participate in activities outside the class and/or avoid situations like entering the world of work.

The reasons behind the motivation of learning divided into 6 main groups by BOSHIER (1982):

- searching for social contachts - the desire to cooperate with others,

- searching for social impulse - the desire to get out of the private life,

- professional development - more stable financial background, the desire of a professional career,

- community work - becoming more effective in the community work,

- external expectations - for external pressure, not for selfactualization, but for expectation.

- the desire for knowledge - the aim is to acquire the most knowledge.

Many researchers use the expressions of extrinsic, i.e. external motivation and intrinsic, i.e. internal motivation when analysing the learning motivation in the higher education (Tóth, 2007; STAGE and WILLIAMS 1990; PINTRICH et al. 1993).

\section{Learning style}

Nowadays, the higher education is mostly a standardized service for the mass. Mass education can hardly take the individual student needs, the learning style into consideration. Several researchers agree that knowing the learning style is an extremely useful knowledge for both of the educators and the students. With the learning style in hand, the educator can actually apply a personalized pedagogy, or at least such tools that could be the most effective for the most students' learning style. Nevertheless, the satisfaction of the educators and the students can be enhanced (LUBAWY, 2003).

Whatever reason stand behind the learning, it is important for the individual to take responsibility for their own learning, and their thinking, feelings, actions should be formed according to that (PIEROG et al. 2016). Knowing the learning style supports the person's responsibility in his own development.

Several researchers have been trying to describe the learning styles, however, because of the lack of conceptual frames, both the learning style theory and its measurement have been continuously criticized (ROMANELLY et al. 2009). A benchmark definition of "learning styles" is: "characteristic cognitive, effective, and psychosocial behaviours that serve as relatively stable indicators of how learners perceive, interact with, and respond to the learning environment (CURRY, 1981).'

According to BALOGH (1993) the learning style is the set of style characteristics in the individual learning of a learner. MEZŐ (2002) argues that the learning style means the preferred external and internal learning conditions.

The model of KOLB (1984) describes four types of learning styles (Cserné, 2008), which are basically different abilities and all of them are needed for a successful learning process, however, the people are different in which they prefer among them.

\section{Its dimensions:}

- $\quad$ concrete (getting concrete experiences) - abstract (creating abstract concepts);

- active (active, experimenting) - reflective (reflective observation).

At some development our aim can be that the neglected fields would also be involved in the learning process based on the strengths. The four dimensions of the four learning styles are the following (Cserné, 2008):

1. Accommodating. Its strength is the active experimentation based on the concrete experiences. Intuitive, actionoriented, adapts well to the circumstances. Feelings are very important in his learning, he likes learning with others. He appreciates the human relations, the more realistic situations, and opened to solve problems. He is intent on applying the acquired knowledge.

2. Diverging, opened. He collects concrete information, experience, he is a reflective observer. He processes the information through observation and understanding. He can create many answers by imagination and problemsolving.

3. Assimilating. This style is characterized by the abstract conceptualization and theoretical observation. He collects the experiences through observation, creates theoretical models, but he does not really deal with the practical application.

4. Converging. He applies abstract information in a practical and action-oriented way, aim and plan-oriented. 
Honey és Mumford (DE VITA, 2001) developed an alternative tool, called LSQ - Learning Style Questionnaire). This tool has been developed in its validity and predictive preciseness compared to its former types.

According to this method there are four distinct types of learners:

- activists (learn primarily by experience),

- reflectors (learn from reflective observation),

- theorists (learn from exploring associations and interrelationships),

- and pragmatics (learn from doing or trying things with practical outcomes).

An alternative of LSQ is the CLSI (CanПeld Learning Style Inventory), which determined again 4 dimensions concerning the learning styles. These dimensions take the learning conditions, the interests, the learning method and the performance criteria into consideration (CANFIELD, 1992).

\section{MATERIAL AND METHOD}

The primary research was done in April-May in 2017 in the circle of students at University of Debrecen. During our survey quantitative methodical elements were applied by paper-based and online questionnaire. The questionnaire had 3 parts: in the first part we asked questions on their motivation and plans to study further which was followed by a learning motivation and a learning style part. To measure the motivation and learning style, tests in the work of BORBÉLY et al. (2017) were used.

The motivation part contained 30 statements about what motivates them in their studies. Students had to consider these sentences and mark if it is true for themselves. For help in the decision, they were suggested to choose those which like on the Likert-scale from 1 to 5 (where 1 meant that it is not characteristic for him at all, 5 is absolutely true) are in the value of 4 or 5 .

The questionnaire divided the statements into six groups:

1. Motivated by long-term goals - planning on long term, to get better job and opportunities in life.

2. Motivated by their own interest - having internal curiosity and interest.

3. Motivated by the learning as a task - hard-working, persistent behaviour.

4. Motivated by results from sense of duty - better marks, higher scores are important from sense of duty.

5. Motivated by recognition - recognition of others is important.

6. Motivated by rewards - reward for the good performance, primarily in the family.

In the learning style test the students had to rank 24 statements in groups of four sentences from 1 to 4 (4 points for the most characteristic feature, 3 points for the less characteristic, 2 for the even less characteristic, and 1 point for the least characteristic). In one group one sentence can only get one type of point. According to the points, this learning style model divides the students into four dimensions (yellow, green, blue, red) if they have theoretical or practical interest, and organised or disorganized.

- Students in the yellow zone have theoretical interest and they are organised. They like reading, working from books and other sources during their studies or work. They like paper work and prefer working alone than in teams. They plan their learning and its process in a sound way.

- Green people are practical and organised. They like if they are told exactly what to do. They love the regularity and paying close attention to the details. They prefer practical work and executing the tasks step by step.

- The red are practical and disorganized. They like challenges, so if there is a problem to be solved, they are happy to elaborate their own new ideas. They are fond of understanding and seeing the problem through.

- People in the blue section are theoretical and disorganized. They love if they can work with people, since they like discussing things with others. They understand others' feelings well. They use their imagination very often, they are creative, like the drama, arts and music.

225 students participated in our survey, 39\% of them are male and $61 \%$ are female in the sample. All questionnaire were valuable, so the sample contained 225 answerers. The youngest was 20 , the oldest was 24 years old in the examined sample, their average age was 22.23 years. $80 \%$ of the questioned are studying on Bachelor's level, the others are on Master's. Mostly students from majors of Tourism and catering (30\%), Commerce and marketing $(21 \%)$ and Finance and accounting (19\%) filled in the questionnaire. Almost half of the participants (49\%) would like to work after finishing their studies, $43 \%$ would like to study further at a higher education institute. Approximately $8 \%$ of the students would like to both work and study simultaneously. More than onefourth (26\%) of the students who said that they wanted to work after their studies admitted that they imagine their life by starting their own company right after graduation.

\section{RESULTS AND DISCUSSION Motivation of the students}

The six types of motivation in the sample are presented in Figure 1. The questionnaire consisted statements and the respondents had to mark those which were typical or absolutely typical for them (4-5 in the Likert-scale from 1 to 5). The statements belonged to 6 motivation groups.

Among the motivators, the intrinsic (internal) motivations are the ones by long-term goals, by interests and the learning as a task itself. Extrinsic (external) motivating factors are the rewards, the recognition, and the results. According to the research results, the following sequence can be set up:

1. Motivated by long-term goals - intrinsic motivator

2. Motivated by recognition - extrinsic motivator

3. Motivated by their own interest - intrinsic motivator

4. Motivated by rewards - extrinsic motivator

5. Motivated by the learning as a task - intrinsic motivator

6. Motivated by results from sense of duty - extrinsic motivator

Figure 1. Different motivating factors in the sample $(N=225)$ 
Source: own research results, 2017

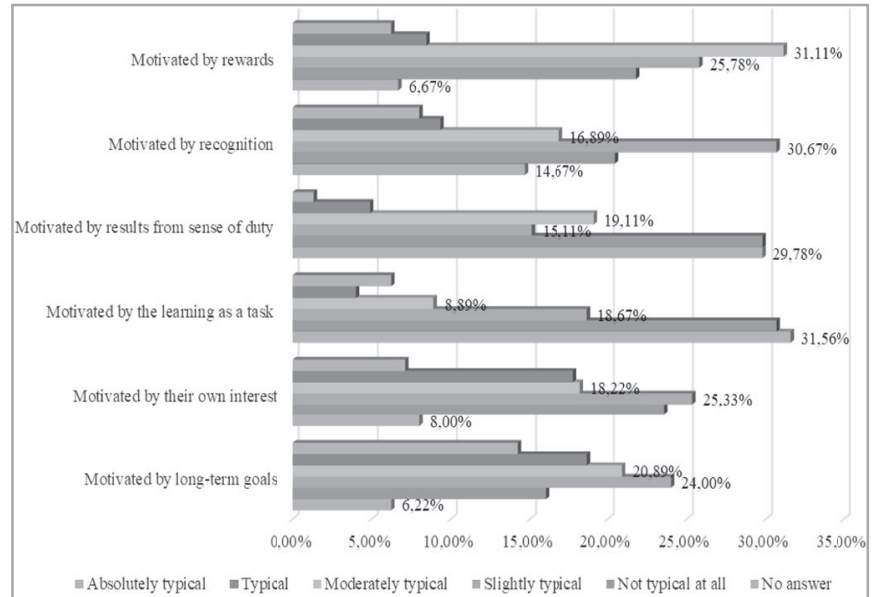

Among the extrinsic motivators, the highest value is the 'moderately typical' in the category of 'Motivated by rewards'. The least typical in the examined sample is the motivation by the learning as a task. The 'absolutely typical' category was the lowest in case of the 'motivation by results from sense of duty'.

Figure 2. shows the evaluation of the statements (\%).It shows that those statements got the highest values which connect to some recognition, achieving success, reward, which are mostly external motivators with some exceptions.

Figure 2. Evaluation of the statements in the sample $(N=225)$

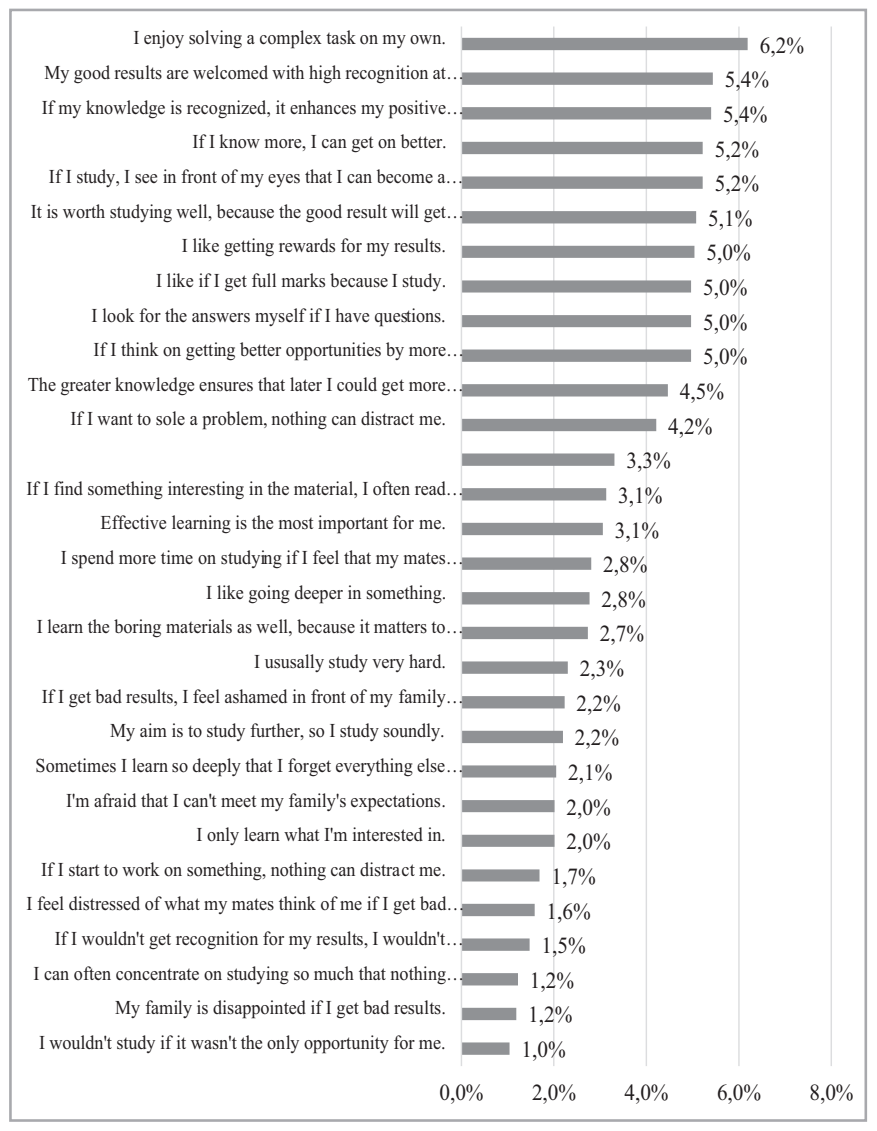

Source: own research results, 2017

\section{LEARNING STYLE OF THE STUDENTS}

Statements of measuring the learning style and their average values are shown in Figure 3. in descending order. The colour of the columns shows which statement belongs to which learning style. It is eye-catching based on the colours that the highest average values belong to the green colour, so it means that most of the questioned students are practical and organized. Statements of the yellow learning style (theoretical, organised) got the lowest scores.

The statement about that 'The students like if the work is enjoyable' got the highest value, which is followed by the fact that they like the practical work. It is common among the questioned that they like the regularity and they think they understand others' feelings quite well. They like working individually and if they can try out their new ideas.

In the middle third of the statements there are ones concerning exactitude and attention, and that they like meeting problems to be solved and planning the solution step by step. Furthermore, they are keen on dealing with others.

The least they like if they have to do paper work and if they have to work from books and other sources. They do not even have good feelings if they are told what to do exactly and they do not plan their learning in details.

Figure 3. Evaluation of the statements of the learning styles $(N=225)$

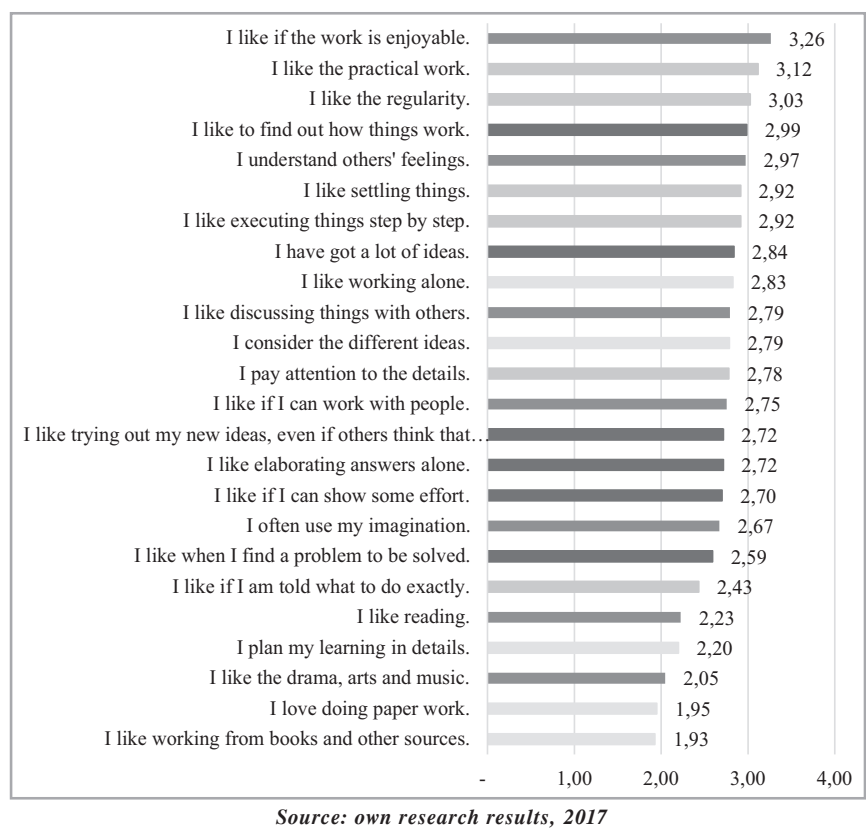

Figure 4. shows the summarized results. These values were calculated in a way that the scores were summed by respondents and after that the average of the sums was received for each statements.

Based on the results we can state that most of the questioned students belong to the green learning style (practical, organised type; 17.19), after that the red one follows is by less than 0.64 (practical, disorganised; 15.55). Then comes the blue learning style (theoretical, disorganised; 15.50). The lowest value belonged to the statements of the yellow type (13.92) who have theoretical interest and disorganise in their learning. 
Figure 4. Learning styles of the surveyed students $(N=225)$

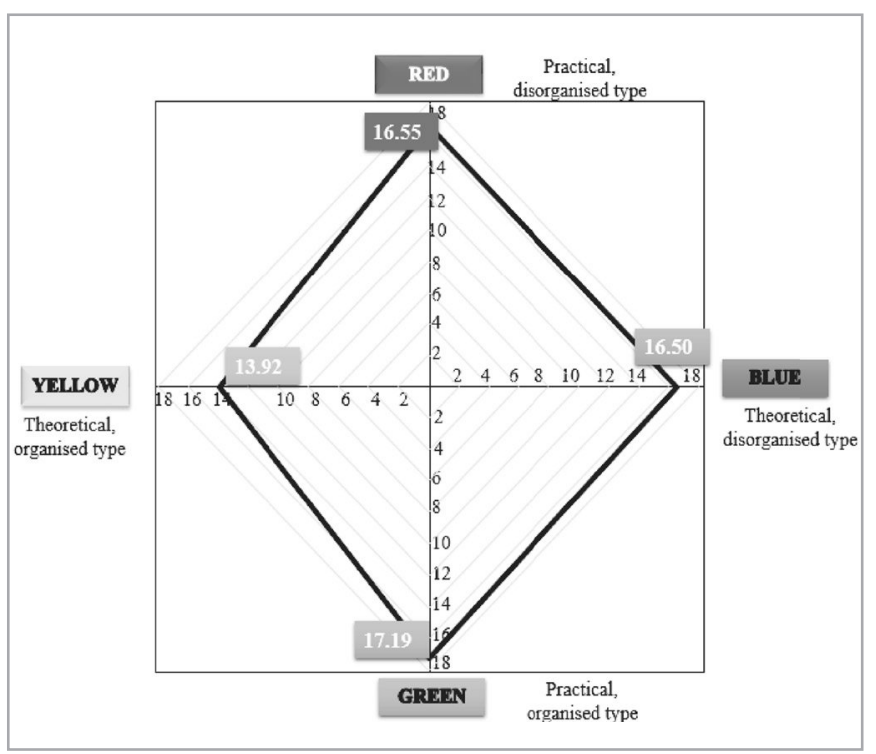

Source: own research results, 2017

\section{CONCLUSIONS}

It can be concluded in general that recent students at universities have the need for the joy of exploration and getting the practice-oriented knowledge in the learning. They are mostly motivated by long-term goals and rewards. These young adults like team work and collaboration with others. This was also proved by this research that they prefer the cooperation, thinking with others, using their creativity to solve complex tasks and to use the theoretical knowledge in practice. Instead of written materials and books, they would like to learn through practice. Therefore, it is advisable to change the conventional frontal teaching with practice-oriented teaching/learning methods, like action-learning, inquiry learning, or project-based learning. These are called inductive learning methods which can be easily applied even at a normal classroom. If such methods are used in the education which cause joy during the learning of the students, they will become more motivated and interested in what they learn. On a longer term, this way they could start to learn to direct their own learnings, so they will be able to leave the university as open-minded adults who care about their own development in their professional life.

Actually, taking the students' or individuals' learning styles into consideration is not a novel thing. It is included in the training methodology of adult education and in the soft skill development on corporate, business level, such as training, mentoring, coaching, etc. It is easier to pique the individuals' personal motivation if his preferred learning style is taken into account. Thus, the authors believe that such development in methodology and curricula would be justified at every education level.

\section{REFERENCES}

Balogh, L. (1993): Tanulási stratégiák és stílusok, a fejlesztés pszichológiai alapjai. Debrecen. KLTE.

Báthory, Z. (1992): Tanulók, iskolák, különbségek. Tankönyvkiadó. Budapest.

Boda, Gy. - Stocker, M. (2012): Outputfinanszírozás a felsőoktatásban. In: Felsőoktatás-finanszírozás. Nemzetközi tendenciák és a hazai helyzet. Aula, Budapest, pp. 293-319. ISBN 978-963-339-032-0

Borbély, A. - Botos, R. - Turcsik, K. (2017): Tanulásmódszertan 1. http://www.oveges.hu/wpcontent/uploads/2013/01/TanModszertan_II_blokk (downloaded: 2017. 06. 15.)

Boshier, R. (1982): The Education Participation Scale. Learning Press, Vancouver

CanПeld, A. (1992). CanПeld Learning Styles Inventory Manual. Los Angeles: Western

Curry, L. (1981). Learning preferences in continuing medical education. Canadian Medical Association Journal.124:535-6.

Cserné Adermann, G. (2008): Tanulási stílusok és képzési stratégiák. In Andragógiai ismeretek (Szerk.: Benedek, A.; Koltai, D.; Szekeres, T.; Vass, L.) Budapest. Nemzeti Szakképzési és Felnőttképzési Intézet, Tanár-továbbképzési Füzetek III.

De Vita, GD. (2001): Learning styles, culture and inclusive instruction in the multicultural classroom: a business and management perspective. Innovations Educ Teaching Int. 2001;38:165-74.

Farrington, D. (2002): A Survey of Student-institution Relationships in Europe. In: OECD (szerk.): Responding to Student Expectations. OECD, Paris, 152 p., 115-130. p.

Horváth, L. (2014): A tudás versenyképességének biztosítása, mint a felsőoktatás negyedik missziója: Hallgatói elégedettség és elvárások szolgáltatásmarketing szemszögből a magyar felsőoktatásban. Szent István Egyetem. Diplomadolgozat.

Houle, C. O. (1961): The inquiring mind. Madison, WI: University of Wisconsin Press.

Mihály, N. (2008): Hallgatói elégedettség kritériumai a tömegoktatás feltételei között. Doktori értekezés. Szegedi Tudományegyetem. Gazdaságtudományi Kar. Gazdálkodástudományi Doktori Iskola.

Lubawy, WC. (2003): Evaluating teaching using the best practices model. American Journal of Pharmatical Education. 67(3): Article 87.

Psychological Services.

Pierog, A.- Erdei, P. - Gergely, É. (2016): A Z generáció vezetőkkel szembeni elvárásai. International Journal of Engineering And Management Sciences, Vol. 1., (No. 1) http://ijems.lib. unideb.hu/cikk/cikk/57aa317508a40. (downloaded: 2016.06.27.)

Pintrich, P.R., Smith D.A.F., Garcia T. \& McKeachie W.J. (1993): Reliability and predictive validity of the motivated strategies for learning questionnaire (MSLQ), Educational and Psychological Measurement, 53, pp. 801-803.

Romanelli, F. \& Bird, E. \& Ryan, M. (2009). Learning Styles: A Review of Theory, Application, and Best Practices. American Journal of Pharmaceutical Education 2009; 73 (1) Article 9.

Roóz, J. - Heidrich, B. (2013): Vállalati gazdaságtan és menedzsment alapjai. http://www.tankonyvtar.hu/hu/tartalom/tamop412A/0007_c1_1054_1055_1057_vallalatigazdtan_scorm/adatok. html (downloaded: 2016.06.2.27.)

Stage, F. K. - Williams, P. D. (1990): Students' motivation and changes in motivation during the first year of college.. Journal of College Student Development, Vol 31(6), Nov 1990, 516-522.

Tóth, L. (2007): Pszichológia a tanításban, Budapest. Pedellus 158.159.719.p 
